\title{
Visual Disturbance in Patients with Cryptococcal Meningitis: The Road Ahead
}

Sir,

Visual disturbances including visual loss have been reported in up to $40 \%$ of patients with cryptococcal meningitis (CCM) ${ }^{[1,2]}$ However, there are no clear guidelines regarding the diagnosis, follow-up, and management of visual complications of CCM. Formulation of evidence-based guidelines has been limited by the incomplete understanding of its pathogenesis. We aimed to evaluate the prevalence of visual disturbances in patients with CCM and its association with clinical and radiological features of raised intracranial pressure (ICP).

In this single-center, retrospective, observational study conducted in a tertiary care center in India, seventy patients with CCM were included over 10 years. Two investigators independently extracted data from inpatient records. Severe headache, depressed sensorium, and papilledema were considered as clinical

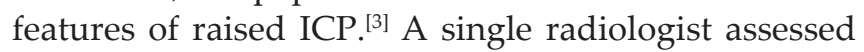
the radiological features of raised ICP (flattening of the posterior sclera, increased cerebrospinal fluid [CSF] in the arachnoid space around the optic nerve, tortuosity of the optic nerve, and partially empty sella). ${ }^{[3]}$ Among the 70 patients with CCM, $13(18 \%)$ had a significant visual disturbance. Of the 13 patients, 10 (76\%) had symptoms, $7(53 \%)$ had papilledema, and $10(76 \%)$ had radiological features of raised ICP [Table 1]. All the 13 patients had symptoms, papilledema, or radiological evidence of raised ICP, and 6/13 patients had all the three features. Nine patients $(69 \%)$ were HIV infected and three $(23 \%)$ succumbed to the illness. Seven patients (53\%) required either repeated therapeutic CSF drainage or ventriculoperitoneal (VP) shunt for raised ICP. However, the patients could not be followed up for the assessment of long-term visual outcomes.

As early as 1993, Rex et al. proposed the two major mechanisms of visual disturbances in CCM, namely raised ICP and optic neuritis. ${ }^{[4]}$ According to these authors, early onset visual disturbance (within 6 days of meningitic symptoms) was a result of optic neuropathy due to infiltration or inflammation, and late-onset visual disturbances which occurred a few weeks into the infection were the result of optic disc edema from raised ICP. More recently, Moodley et al. proposed optic nerve sheath compartment syndrome as another possible mechanism of visual disturbance in CCM. ${ }^{[5,6]}$ Other postulated pathophysiological mechanisms include cortical blindness secondary to cerebral vasculitis, cryptococcus-related anterior uveitis, chorioretinitis, endophthalmitis, and retinovitreal abscess.

There has been anecdotal evidence that visual loss due to raised ICP is mostly reversible and amenable to therapeutic strategies of reducing the ICP such as repeated lumbar punctures, acetazolamide, lumboperitoneal shunt, lumbar drain, VP shunt, and optic nerve sheath

Table 1: Baseline clinical, laboratory, and imaging findings and outcome of patients with cryptococcal meningitis and visual disturbance

\begin{tabular}{|c|c|c|c|c|c|c|c|c|c|}
\hline \multirow[t]{2}{*}{ Age/sex } & \multirow{2}{*}{$\begin{array}{l}\text { Visual } \\
\text { disturbances }\end{array}$} & \multicolumn{3}{|c|}{ Increased intracranial pressure } & \multirow[t]{2}{*}{ GCS } & \multirow{2}{*}{$\begin{array}{l}\text { Therapeutic CSF } \\
\text { drainage }\end{array}$} & \multirow[t]{2}{*}{ CD4 } & \multirow[t]{2}{*}{ Risk factors } & \multirow[t]{2}{*}{ Mortality } \\
\hline & & Symptoms & Papilledema & $\begin{array}{l}\text { Radiological } \\
\text { evidence }\end{array}$ & & & & & \\
\hline 57/male & $\mathrm{B} / \mathrm{L}$ & No & No & Yes & 15 & Yes & 690 & Diabetes & Yes \\
\hline 34/male & Right & Yes & No & No & 14 & Yes & 12 & HIV & No \\
\hline 43/female & $B / L$ & Yes & Yes & Yes & 15 & Yes & 288 & None & No \\
\hline 42/female & $B / L$ & No & No & Yes & 15 & Yes & 493 & None & No \\
\hline 30/male & $B / L$ & Yes & Yes & No & 13 & No & 27 & HIV & Yes \\
\hline 26/female & $B / L$ & Yes & Yes & Yes & 15 & No & 29 & HIV & Yes \\
\hline 33/female & $B / L$ & No & No & Yes & 15 & No & 70 & HIV & No \\
\hline 40/male & $B / L$ & Yes & Yes & Yes & 15 & No & 380 & HIV & No \\
\hline $36 /$ male & $B / L$ & Yes & Yes & Yes & 15 & Yes & 159 & HIV & No \\
\hline $27 /$ male & $B / L$ & Yes & Yes & Yes & 11 & VP shunt & 474 & None & No \\
\hline $41 /$ male & $B / L$ & Yes & Yes & Yes & 15 & No & 40 & HIV & No \\
\hline 37/male & $B / L$ & Yes & No & Yes & 15 & No & 114 & HIV & No \\
\hline $37 /$ male & $B / L$ & Yes & No & No & 15 & Yes & 47 & HIV & No \\
\hline
\end{tabular}

B/L: Bilateral, GCS: Glasgow Coma Scale, HIV: Human immunodeficiency virus, CSF: Cerebrospinal fluid, VP: Ventriculoperitoneal 
fenestration. However, the recent CryptoDex study did not find any benefit with adjunctive dexamethasone treatment. ${ }^{[7,8]}$

We found a significant association between visual disturbance and elevated ICP in patients with CCM. Based on our finding, we suggest formal assessment of visual acuity in patients with CCM and evaluation for raised ICP in those with visual disturbances. However, these suggestions need to be validated in a prospective study.

\section{Financial support and sponsorship}

This study was financially supported by Institutional Fluid Research Grant.

\section{Conflicts of interest}

There are no conflicts of interest.

Cijoy K. Kuriakose, Ajay Kumar Mishra, Harshad Arvind Vanjare ${ }^{1}$, Ancy Raju², O. C. Abraham

Departments of General Medicine, ${ }^{1}$ Radiology and ${ }^{2}$ Ophthalmology, Christian Medical College, Vellore, Tamil Nadu, India

Address for correspondence: Dr. Cijoy K. Kuriakose, Department of Medicine Unit IV, Christian Medical College and Hospital, Vellore - 632 004, Tamil Nadu, India. E-mail: cijoy_kuriakose@yahoo.com

\section{References}

1. Sloan DJ, Parris V. Cryptococcal meningitis: Epidemiology and therapeutic options. Clin Epidemiol 2014;6:169-82.

2. Battu RR, Biswas J, Jayakumar N, Madhavan HN, Kumarsamy N, Solomon S. Papilloedema with peripapillary retinal haemorrhages in an acquired immunodeficiency syndrome (AIDS) patient with cryptococcal meningitis. Indian J Ophthalmol 2000;48:47-9.

3. Chandiraesharan VK, Mishra AK, Koshy M, Mani SE. Uncommon presentation of idiopathic intracranial hypertension. Arch Med Health Sci 2015;3:285-7.

4. Rex JH, Larsen RA, Dismukes WE, Cloud GA, Bennett JE. Catastrophic visual loss due to Cryptococcus neoformans meningitis. Medicine (Baltimore) 1993;72:207-24.

5. Moodley A, Rae W, Bhigjee A. Visual loss in HIV-associated cryptococcal meningitis: A case series and review of the mechanisms involved. S Afr J HIV Med 2015;16:9.

6. Moodley A, Rae W, Bhigjee A, Connolly C, Devparsad N, Michowicz A, et al. Early clinical and subclinical visual evoked potential and Humphrey's visual field defects in cryptococcal meningitis. PLoS One 2012;7:e52895.

7. Beardsley J, Wolbers M, Kibengo FM, Ggayi AB, Kamali A, Cuc NT, et al. Adjunctive dexamethasone in HIV-associated cryptococcal meningitis. N Engl J Med 2016;374:542-54.

8. Moosa MY, Coovadia YM. Cryptococcal meningitis in Durban, South Africa: A comparison of clinical features, laboratory findings, and outcome for human immunodeficiency virus (HIV)-positive and HIV-negative patients. Clin Infect Dis 1997;24:131-4.

This is an open access article distributed under the terms of the Creative Commons Attribution-NonCommercial-ShareAlike 3.0 License, which allows others to remix, tweak, and build upon the work non-commercially, as long as the author is credited and the new creations are licensed under the identical terms.

\begin{tabular}{|l|l|}
\hline \multicolumn{2}{|c|}{ Access this article online } \\
\hline Quick Response Code: & Website: \\
\hline & www.ruralneuropractice.com \\
\cline { 2 - 2 } & \\
\hline
\end{tabular}

How to cite this article: Kuriakose CK, Mishra AK, Vanjare HA, Raju A, Abraham OC. Visual disturbance in patients with cryptococcal meningitis: The road ahead. J Neurosci Rural Pract 2017;8:151-2. 